(D) Check for updates

Cite this: Food Funct., 2018, 9, 3134

\title{
Melissa officinalis L. ethanolic extract inhibits the growth of a lung cancer cell line by interfering with the cell cycle and inducing apoptosis
}

\author{
D. B. Magalhães, $\uparrow^{a, b, c}$ I. Castro, $\dagger^{b, c, d}$ V. Lopes-Rodrigues, ${ }^{b, c}$ J. M. Pereira, $, c, c$ \\ L. Barros, (D) ${ }^{e}$ I. C. F. R. Ferreira, (DD ${ }^{* e}$ C. P. R. Xavier (D) ${ }^{b, c}$ and M. H. Vasconcelos (D) $* a, b, c$
}

\begin{abstract}
Melissa officinalis is a plant from the family Lamiaceae, native in Europe particularly in the Mediterranean region. Given our interest in identifying extracts and compounds capable of inhibiting tumor cell growth, and given the antioxidant content and the high consumption of Melissa officinalis in Portugal, this study aimed to test the tumor cell growth inhibitory activity of five different extracts of this plant (aqueous, methanolic, ethanolic, hydromethanolic and hydroethanolic) in three human tumor cell lines: MCF-7, AGS and $\mathrm{NCl}-\mathrm{H} 460$. All extracts decreased cell growth in all cell lines in a concentration-dependent manner. The ethanolic extract was the most potent one, presenting a $\mathrm{Gl}_{50}$ concentration of approximately $100.9 \mu \mathrm{gL} \mathrm{m}^{-1}$ in the $\mathrm{NCl}-\mathrm{H} 460$ lung cancer cells. This extract was characterized by LC-DAD-ESI/MS regarding its phenolic composition, revealing rosmarinic acid as the most abundant compound. The $\mathrm{Gl}_{75}$ concentration of this extract affected the cell cycle profile of these cells. In addition, both the $\mathrm{Gl}_{50}$ and the $\mathrm{Gl}_{75}$ concentrations of the extract induced cellular apoptosis. Moreover, treatment of $\mathrm{NCl}-\mathrm{H} 460$ cells with this extract caused a decrease in pro-caspase 3 and an increase in p53 levels. This study emphasizes the relevance of the study of natural products as inhibitors of tumor cell growth.
\end{abstract}

Received 9th March 2018 Accepted 23rd April 2018

DOI: $10.1039 / \mathrm{c} 8 \mathrm{fo} 00446 \mathrm{c}$ rsc.li/food-function example is paclitaxel (Taxol), derived from Taxus brevifolia (from the family Taxaceae) and currently clinically used in the treatment of breast cancer. ${ }^{5,6}$

Melissa officinalis is one of the most used medicinal plants in Europe and in the Mediterranean region, where it is known as lemon balm or, in Portugal, as "erva-cidreira" or just "cidreira". ${ }^{7}$ The leaves of this plant are used to reduce anxiety, promote sleep and improve symptoms of indigestion. ${ }^{8}$ Some studies have also reported antibacterial, antifungal and antiinflammatory activities, ${ }^{9}$ while others have reported antitumoral effects for some Melissa officinalis extracts on some human tumor cell lines. ${ }^{10-12}$ In order to understand the antitumor activity of this plant, several studies have been conducted to learn more about its composition. M. officinalis is composed of polyphenolic compounds such as caffeic acid derivatives (mostly rosmarinic acid), flavonoids and essential oil. In addition, it is constituted of glucose (the most abundant sugar) and vitamins $\mathrm{E}$ and $\mathrm{C}$, which have important activity as inactivators of free radicals. ${ }^{13}$

The cell growth inhibitory potential of Melissa officinalis was previously studied in some human tumor cell lines. However, the cellular mechanism responsible for its cell growth inhibitory potential has never been studied. Therefore, the aim of this work was to study the effect of different extracts of Melissa officinalis (ethanolic, methanolic, hydromethanolic, 
hydroethanolic and aqueous extracts) on the growth of three cell lines representative of different types of cancer: the NCI-H460 cell line from non-small cell lung cancer, the MCF-7 cell line from breast adenocarcinoma and the AGS cell line from gastric adenocarcinoma. The most potent extract was further studied in the most sensitive cell line regarding the effect on cell morphology, cell cycle profile and apoptosis.

\section{Materials and methods}

\section{Samples and preparation of Melissa officinalis extracts}

Melissa officinalis L. dry leaves were collected in Alfândega da Fé (Trás-os-Montes, Northeastern Portugal) in February 2016.

\section{Preparation of the infusion extract}

The preparation of the infusion extracts was carried out according to the previously described protocol, ${ }^{14}$ by extracting $1 \mathrm{~g}$ of the dry leaves with $200 \mathrm{~mL}$ of boiled water (heating plate, VELP Scientific) and allowing the extract to stand at room temperature for 5 minutes. After filtration through Whatman no. 4 filter paper, the obtained infusions were frozen and lyophilized.

\section{Preparation of the hydromethanolic, hydroethanolic, methanolic and alcoholic extracts}

To obtain the hydromethanolic, hydroethanolic, methanolic and ethanolic extracts, $1 \mathrm{~g}$ of the dry leaves was extracted twice with $30 \mathrm{~mL}$ of methanol : water and ethanol : water $(80: 20, \mathrm{v} / \mathrm{v})$ and with $30 \mathrm{~mL}$ methanol or ethanol, respectively, in a stirring plate (at $25{ }^{\circ} \mathrm{C}$ and $150 \mathrm{rpm}$ ) for 1 hour. After filtration through Whatman no. 4 filter paper, the final residue of each extract was then evaporated at $40^{\circ} \mathrm{C}$ under reduced pressure, using a rotary evaporator (Büchi R-210, Flawil, Switzerland).

Stock solutions of all extracts were prepared in $100 \%$ sterile DMSO (methanolic and ethanolic extract) or water (aqueous, hydromethanolic and hydroethanolic) at a final concentration of $100 \mathrm{mg} \mathrm{mL}^{-1}$ and further stored at $-20^{\circ} \mathrm{C}$.

\section{Cell culture}

The three human tumor cell lines used in this study were MCF-7 (breast adenocarcinoma, from ECACC), NCI-H460 (nonsmall cell lung cancer, a kind gift from NCI, Bethesda, MD, USA) and AGS (gastric adenocarcinoma, from ATCC). These adherent cell lines were maintained in RPMI-1640 medium with Ultra-glutamine I (Lonza, Basel, Switzerland) supplemented with heat-inactivated bovine fetal serum (FBS, Biowest, Riverside, MO, USA). The FBS concentration used was $5 \%$ for the cell growth inhibitory assay and $10 \%$ for the remaining assays. Cultures were incubated in the presence of $5 \% \mathrm{CO}_{2}$ at $37{ }^{\circ} \mathrm{C}$. Cells were routinely observed with an inverted microscope (Nikon eclipse TS100 microscope) to analyse their number and morphology. Passages were made when confluence reached $80-90 \%$ by trypsinization with TrypLE ${ }^{\text {тм }}$ Express (Life Technologies, Carlsbad, CA, USA) and gentle mechanical detachment. The viable cell number was regularly determined with the trypan blue $(1: 1)$ exclusion assay. All the experiments were performed only when exponentially growing cells presented more than $90 \%$ viability.

\section{Phenolic characterization}

The phenolic profile was analysed through a LC-DAD-ESI/MS system (Dionex Ultimate 3000 UPLC, Thermo Scientific, San Jose, CA, USA). Detection was performed using a diode array detector (DAD, 280, 330 and $370 \mathrm{~nm}$ as preference wavelengths) and coupled to a mass spectrometer (Linear Ion Trap LTQ XL mass spectrometer, Thermo Finnigan, San Jose, CA, USA), following a procedure previously described by Bessada, Barreira, Barros, Ferreira \& Oliveira (2016). ${ }^{15}$ Phenolic compound quantification was performed through the calibration curves of phenolic standards (caffeic acid, ferulic acid, rosmarinic acid, Sigma-Aldrich, St Louis, MO, USA) and the results were expressed in $\mathrm{mg}$ per $\mathrm{g}$ of extract.

\section{Cell growth inhibition assay}

The sulforhodamine B (SRB) assay was performed according to the in vitro anti-cancer drug screening procedure of the National Center Institute (NCI). ${ }^{16}$ Cells were plated in 96-well plates at the previously determined optimal cell concentration. In the case of MCF-7 and NCI-H460 cells, the appropriate cellular density was $5.0 \times 10^{4}$ cells per well ${ }^{17,18}$ and for the AGS cells the cellular density was $7.5 \times 10^{4}$ cells per well. ${ }^{19}$ Two plates were prepared, one to be analysed at the time of addition of the extracts to cells (T0 plate) and the other to be analysed 48 hours after treating the cells with the extracts. Cells were incubated for 24 hours to allow cells to adhere to the plate. In the T48 plate (TPP® Tissue Culture Plates), cells were then treated with five serial dilutions of each extract, ranging from $400 \mu \mathrm{g} \mathrm{mL} \mathrm{m}^{-1}$ to $25 \mu \mathrm{g} \mathrm{mL}^{-1}$. Doxorubicin (DOXO) was used as a positive control, in successive $1: 2$ dilution ranging from $150 \mathrm{nM}$ to $9.37 \mathrm{nM}$. The effect of the solvents of the extracts, DMSO or water, on the growth of the cell lines was also evaluated (as controls) by treating cells with the maximum concentration used. After 48 hours of incubation with the extracts (or immediately for the T0 plate), cells were fixed by adding ice-cold 10\% trichloroacetic acid (TCA, w/v, Panreac, Barcelona, Spain) and allowed to air-dry. Cells were then stained with $0.4 \%$ sulforhodamine B reagent (SRB, Sigma Aldrich, St Louis, MO, USA) in 1\% (v/v) acetic acid. The bound dye was then solubilized by adding $10 \mathrm{mM}$ of Tris-base solution ( $\mathrm{pH}$ 10.5) (Sigma Aldrich, St Louis, MO, USA). The absorbance was measured at $510 \mathrm{~nm}$ in a microplate reader (BioTek® Synergy HT, Winooski, VT, USA). All the SRB experiments used medium supplemented with $5 \%$ of FBS (Biowest) and $1 \%$ of antibiotic antimycotic solution (100×, SigmaAldrich, St-Louis, MO, USA). The cell number was determined as a percentage, compared to untreated cells. The $\mathrm{GI}_{50}$ concentration (concentration that inhibits $50 \%$ of net cell growth) was assessed from the dose-response curves and determined for each extract and each cell line. 


\section{Preparation of cells for other analysis}

For the analysis of the cell cycle, apoptosis or western blot, the NCI-H460 cells were plated at the density of $1.5 \times 10^{5}$ cells per well in 6-well plates and incubated for 24 hours. Then, the cells were treated with Melissa officinalis ethanolic extract at different concentrations: $100.9 \mu \mathrm{g} \mathrm{mL} \mathrm{m}^{-1}$ (approximately the $\mathrm{GI}_{50}$ concentration) and $180 \mu \mathrm{g} \mathrm{mL} \mathrm{m}^{-1}$ (approximately the $\mathrm{GI}_{75}$ concentration). Blank cells (treated with medium) and control cells (treated with the same concentrations of DMSO as used in treatments with the extract: corresponding to the $\mathrm{GI}_{50}$ treatment - control 1 - and corresponding to the $\mathrm{GI}_{75}$ treatment control 2) were also included. Cells were then centrifuged at $1200 \mathrm{rpm}$ for 5 minutes at $4{ }^{\circ} \mathrm{C}$. For each treatment, the cell number and viability were confirmed by the trypan blue exclusion assay (cells were counted using a hemocytometer and trypan blue reagent; trypan blue penetrates the membrane of dead cells allowing to distinguish them from the alive ones) and analyzed in relation to blank cells.

\section{Analysis of the cell cycle profile}

Following trypsinization and centrifugation, cells were fixed with ice-cold $70 \%$ ethanol and stored at $4{ }^{\circ} \mathrm{C}$ overnight. Prior to analysis, the cells were centrifuged for 5 minutes at $1200 \mathrm{rpm}$ and re-suspended in PBS containing propidium iodide (5 $\mu \mathrm{g} \mathrm{mL} \mathrm{mL}^{-1}$; Sigma Aldrich, St Louis, MO, USA) and RNase A (0.1 mg mL ${ }^{-1}$; Sigma Aldrich, St Louis, MO, USA). Samples were kept on ice for at least 30 minutes. Cellular DNA content was analysed using the flow cytometry (BD AccuriTM C6 Flow cytometry, USA) by analysing at least 20000 events per sample. $^{20}$ The percentage of cells in the G0/G1, S and G2/M phases of the cell cycle were determined using the FlowJo software (version 7.6.0, Tree Star, Inc., Ashland, USA) after cell debris and aggregate exclusion.

\section{Analysis of apoptosis}

For the analysis of apoptosis, after trypsinisation and centrifugation, the pellet of the cells was re-suspended in binding buffer solution from the Annexin V-FITC Apoptosis Detection Kit (eBioscience, Bender MedSystems), as indicated by the manufacturer. The cells were then incubated for 10 minutes with $5 \mu \mathrm{L}$ of human Annexin V-FICT and further incubated for 5 minutes with $10 \mu \mathrm{L}$ of propidium iodide (in the dark and on ice). Samples were then analysed by flow cytometry using the BD Accuri ${ }^{\mathrm{TM}} \mathrm{C} 6$ flow cytometry and respective software, plotting at least 20000 events per sample.

\section{Analysis of protein expression}

Proteins from the different cellular treatments were extracted by centrifugation of the cells at $1000 \mathrm{rpm}$ for 5 minutes followed by lysis of the pellet in Winman's buffer (1\% NP-40, $0.1 \mathrm{M}$ Tris$\mathrm{HCl}$ pH 8.0, $0.15 \mathrm{M} \mathrm{NaCl}$ and $5 \mathrm{mM}$ EDTA) with an EDTA-free protease inhibitor cocktail (Roche, Indianopolis, USA) for 30 minutes at $4{ }^{\circ} \mathrm{C}$ (with agitation). The supernatants (corresponding to cellular proteins) were obtained after centrifugation at $13000 \mathrm{rpm}$, at $4^{\circ} \mathrm{C}$ for 10 minutes. The total cell protein was quantified using a modified Lowry assay (Bio-Rad DC Protein Assay, Hercules, CA, USA). ${ }^{21,22}$ Bovine serum albumin (BSA, Sigma Aldrich, St Louis, MO, USA) was used as a protein standard. After quantification, $20 \mu \mathrm{g}$ of each cell extract was separated on $12 \%$ Bis-Tris SDS-Page gel at $70 \mathrm{~V}$ (for 30 minutes) and then $100 \mathrm{~V}$ (for 1 hour) and transferred to a nitrocellulose membrane (GE Healthcare, Wisconsin, USA) at $100 \mathrm{~V}$ (for 1 hour). Membranes were then blocked in Tris-buffered saline solution with $0.1 \%$ Tween-20 (Promega, Fitchburg, USA) - TBS-T - containing $5 \%(\mathrm{w} / \mathrm{v})$ of non-fat dry milk, for at least 30 minutes with agitation at room temperature. Membranes were then incubated with the following primary and secondary antibodies for 1 hour and 30 minutes or 1 hour, respectively, at room temperature: mouse anti-p53 (Sc-126) (1:5000), mouse anti-caspase 3 (sc-7272) (1:1000) and goat anti-mouse IgG-HRP (1:2000) from Santa Cruz Biotechnology (Heidelberg, Germany) and mouse anti- $\alpha$-tubulin $(1: 10000)$ from Sigma Aldrich (St Louis, MO, USA). The signal from the membranes was detected using the ECL Western Blot Detection Reagents (GE Healthcare, Wisconsin, USA), the Amersham Hyperfilm ECL (GE Healthcare, Wisconsin, USA) and the Kodak GBX developer and fixer (Sigma Aldrich, St Louis, MO, USA). The intensity of the bands of each film was analysed using the software Quantity One - ID Analysis (Bio-Rad), as previously described. ${ }^{23}$

\section{Statistical analysis}

The results of three independent experiments from each ethanolic extract were statistically analyzed using the two-tailed paired Student's $t$-test.

\section{Results and discussion}

\section{Effect of Melissa officinalis on the growth of several human tumor cell lines}

The different extracts (ethanolic, methanolic, hydromethanolic, hydroethanolic and aqueous extracts) of Melissa officinalis were tested for cell growth inhibitory activity in MCF-7, AGS and NCI-H460 tumor cell lines, using the sulforhodamine B (SRB) assay. All the extracts tested presented similar activities in the three studied cell lines, suggesting that they have a nonspecific effect (Fig. 1). Additionally, it is possible to observe that higher concentrations of the ethanolic, the hydroethanolic (only in the NCI-H460 and MCF-7 cells) and the hydromethanolic extracts reduced the cell number to values lower than the number of cells plated at the beginning of the experiment (i.e. the T48 plate had fewer cells than the T0 plate), suggesting that these extracts induce some degree of cell death on these cell lines (Fig. 1).

The most potent extract was the Melissa officinalis ethanolic extract and the most potent effect was observed in the NCI-H460 cells, with a $\mathrm{GI}_{50}$ concentration of $100.9 \mu \mathrm{g} \mathrm{mL}^{-1}$ (Table 1). On the other hand, the aqueous extract was the least potent extract in this study, with values of $\mathrm{GI}_{50}$ always higher than 200 $\mu \mathrm{g} \mathrm{mL}^{-1}$. Saraydin and colleagues tested an aqueous extract of Melissa officinalis and verified that the extract was very potent, 

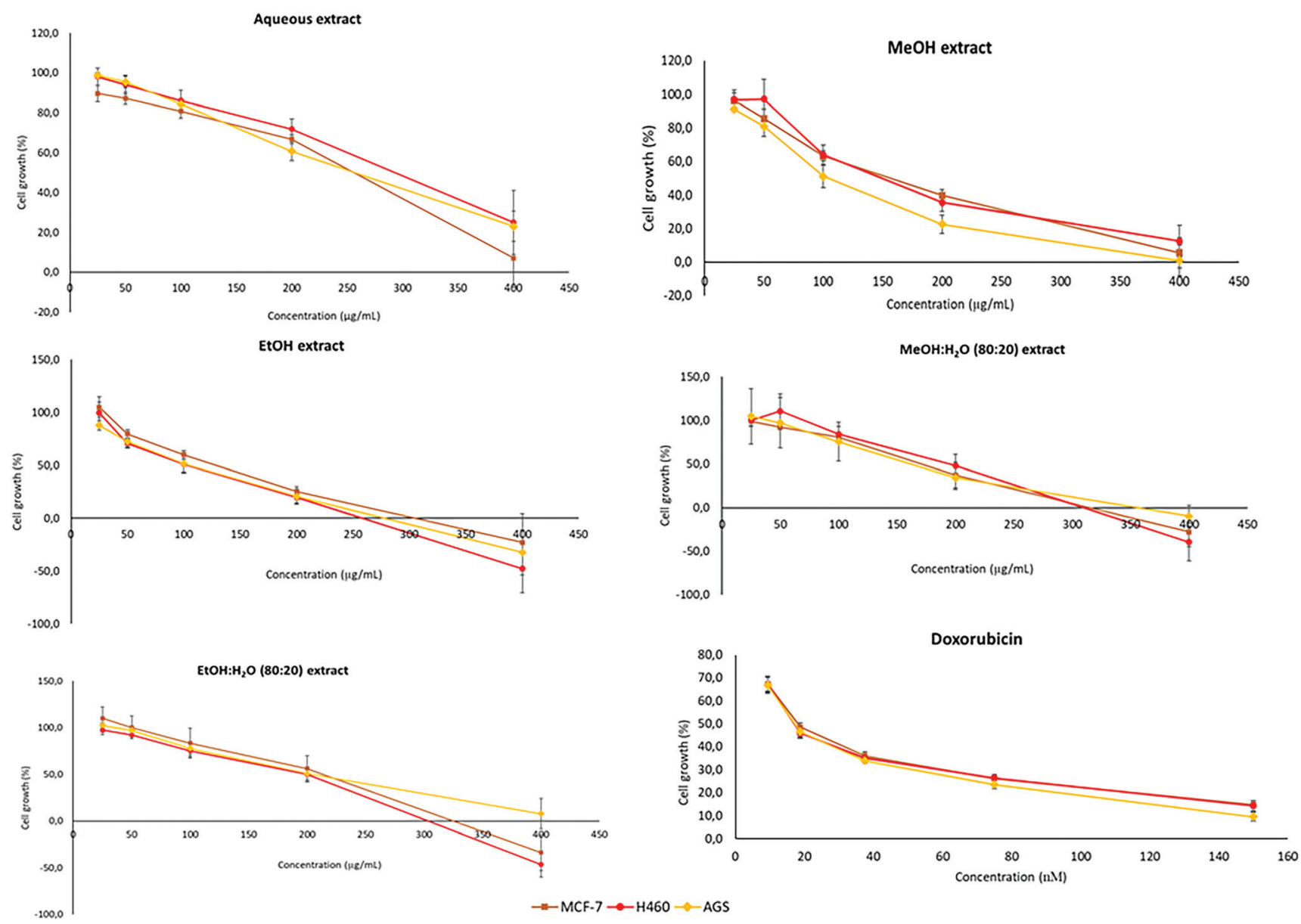

Fig. 1 Dose-response curves of different extracts of Melissa officinalis and doxorubicin (as a positive control). Results were determined with the SRB assay following $48 \mathrm{~h}$ treatment of MCF-7, NCl- 4460 or AGS cells. The extracts were tested at 5 concentrations ranging from $400 \mu \mathrm{mg} \mathrm{mL}{ }^{-1}$ to $25 \mu \mathrm{g} \mathrm{mL} \mathrm{L}^{-1}$. Doxorubicin was tested in successive dilutions ranging from $150 \mathrm{nM}$ to $9.37 \mathrm{nM}$. Results are presented as percentage (\%) of cell growth when compared to blank (untreated cells). Percentage (\%) of growth below zero indicates a decrease in the cell number to values lower than the ones plated at the beginning of the experiment. Results are the mean \pm S.E. of at least 3 independent experiments.

Table $1 \mathrm{Gl}_{50}$ concentrations of different extracts of Melissa officinalis in three human tumor cell lines

$\mathrm{GI}_{50}$ concentrations $\left(\mu \mathrm{g} \mathrm{mL}^{-1}\right)$ in different tumor cell lines

\begin{tabular}{llll}
\cline { 2 - 4 } Melissa officinalis extracts & MCF-7 & NCI-H460 & AGS \\
\hline Aqueous & $270.0 \pm 38.7$ & $260.3 \pm 21.6$ & $251.7 \pm 27.4$ \\
MeOH & $151.6 \pm 15.3$ & $161.3 \pm 2.3$ & $104.0 \pm 14.3$ \\
EtOH & $122.5 \pm 9.0$ & $100.9 \pm 16.2$ & $108.1 \pm 20.6$ \\
MeOH$\cdot \mathrm{H}_{2} \mathrm{O}$ & $181.7 \pm 18.9$ & $197.0 \pm 30.7$ & $166.4 \pm 24.5$ \\
EtOH$\cdot \mathrm{H}_{2} \mathrm{O}$ & $178.8 \pm 28.7$ & $189.6 \pm 22.5$ & $204.4 \pm 29.5$
\end{tabular}

$\mathrm{GI}_{50}$ refers to the concentration that inhibits $50 \%$ of net cell growth. $\mathrm{GI}_{50}$ concentrations represented in this table correspond to the mean \pm S.E. of at least three independent experiments. Doxorubicin was used as a positive control: $17.9 \pm 14.5 \mathrm{nM}$ in MCF-7 cells, $16.7 \pm 1.8 \mathrm{nM}$ in NCI-H460 cells and $16.7 \pm 1.6 \mathrm{nM}$ in AGS cells.

with $\mathrm{IC}_{50}$ concentrations of $18 \mu \mathrm{g} \mathrm{mL}{ }^{-1}$ in MCF-7 cancer cells. ${ }^{12}$ The difference between our results and this study may be explained by the geographic variability of Melissa officinalis - while the plant used in this work was collected in Portugal, the plant used in the work of Saraydin et al. was collected in Turkey - which may influence the natural concentration of the constituents responsible for the antitumor activity. Indeed, the percentage of the constituents in a plant extract is highly influenced by exogenous factors such as temperature, climate, soil quality or the time of the year when the plant is harvested. ${ }^{24}$ Additionally, Saraydin et al. measured the $\mathrm{IC}_{50}$ concentration which represents the concentration that inhibits $50 \%$ of a desired activity, while the $\mathrm{GI}_{50}$ concentration (used in this study) represents the concentration that inhibits $50 \%$ of cell growth.

Given the obtained $\mathrm{GI}_{50}$ concentrations of the different Melissa officinalis extracts on the three human tumor cell lines, the following studies were performed with the most potent extract (ethanolic extract, EtOH) in the most sensitive cell line (NCI-H460).

\section{Phenolic characterization of Melissa officinalis}

The phenolic profile characteristics of the ethanol extract (final concentration of $5 \mathrm{mg} \mathrm{mL}^{-1}$ ) performed by LC-DAD-ESI/MS 
is shown in Table 2. A total of 20 compounds were identified taking into account the identification pattern previously performed by Pereira et al., ${ }^{25}$ using an infusion of M. officinalis. Hydroxycinnamic acid derivatives were the main class of phenolic compounds present in the extract, specifically rosmarinic acid (caffeic acid dimer) was the most abundant compound present. The high levels of this compound in $M$. officinalis have already been mentioned in the literature. ${ }^{26,27}$

\section{Effect of Melissa officinalis on the viability of NCI-H460 cells}

The effect of two concentrations (100.9 $\mu \mathrm{g} \mathrm{mL}^{-1}-$ corresponding to the $\mathrm{GI}_{50}$ concentration - and $180 \mu \mathrm{g} \mathrm{mL}{ }^{-1}$ - corresponding to the $\mathrm{GI}_{75}$ concentration) of the ethanolic extract of Melissa officinalis was analysed in terms of cell viability using the trypan blue exclusion assay. Results (Fig. 2) showed that the ethanolic extract (EtOH), at either of the concentrations used, significantly decreased NCI-H460 cell viability. Treatment with $100.9 \mu \mathrm{g} \mathrm{mL}^{-1}$ of ethanolic extract reduced cell viability to approximately $35 \%$ while treatment with $180 \mu \mathrm{g}$ $\mathrm{mL}^{-1}$ decreased the cell viability to approximately $20 \%$ (when compared to the "blank" cells, Fig. 2G). Neither of the controls (CTR 50 and CTR 75 of DMSO) had a significant effect on cell viability in contrast with the treatment with doxorubicin, the positive control used, which significantly reduced cell viability. In addition, no significant morphological alterations were detected on cells treated with the extract when compared to blank cells (Fig. 2A-F).

\section{Effect of the ethanolic extract of Melissa officinalis on the cell cycle profile and apoptosis of NCI-H460 cells}

In order to understand the effect of the ethanolic extract of Melissa officinalis on the NCI-H460 cell cycle profile, the nuclear DNA content of the cells was analyzed by flow cytometry following $48 \mathrm{~h}$ treatment with the extract. Doxorubicin treatment was used as a positive control for the assay. Results demonstrated that in cells treated with the $\mathrm{GI}_{50}$ concentration of the extract, there were no major alterations in the percen-

Table 2 Phenolic characterization and quantification of $M$. officinalis ethanol extract

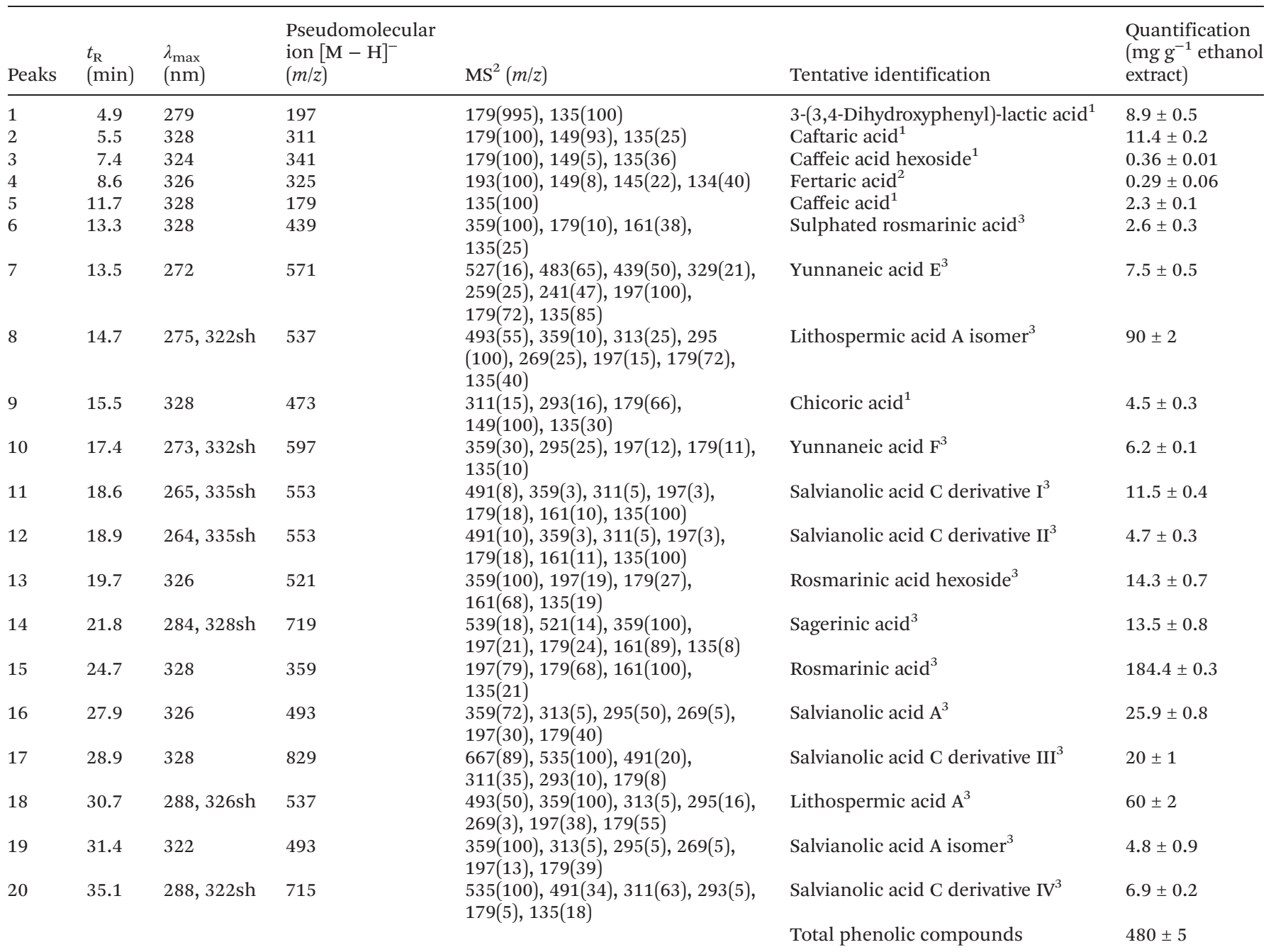

Phenolic compound standards used for the quantification: 1 - caffeic acid, 2 - ferulic acid and 3 - rosmarinic acid. 

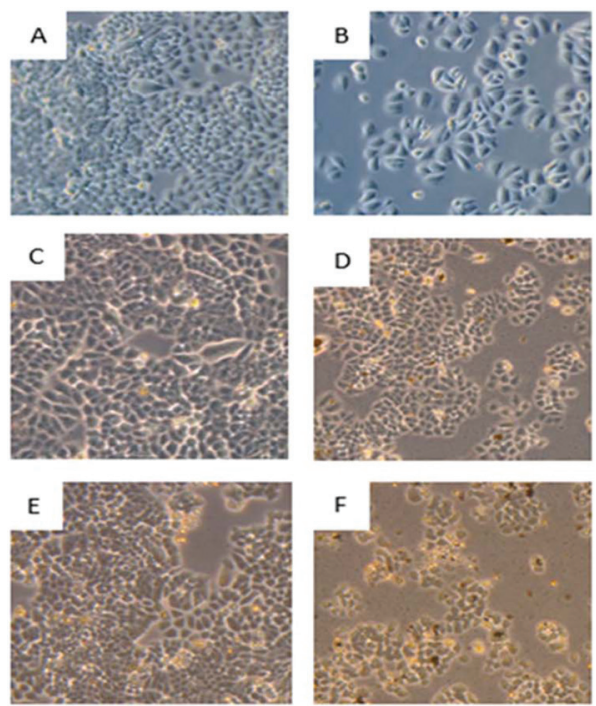

G

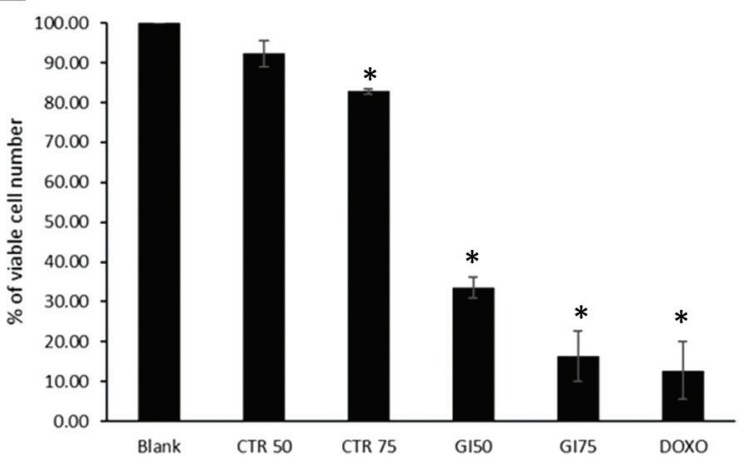

Fig. 2 Representative photographs of $\mathrm{NCl}-\mathrm{H} 460$ human tumor cells treated for $48 \mathrm{~h}$ with the ethanolic extract of Melissa officinalis or with a positive control (doxorubicin). (A) Blank; (B) positive control - doxorubicin; (C) control of the $\mathrm{Gl}_{50}$ concentration of the extract; (D) treatment with the $\mathrm{Gl}_{50}$ concentration of the extract; $(\mathrm{E})$ control of the $\mathrm{Gl}_{75}$ concentration of the extract and (F) treatment with the $\mathrm{Gl}_{75}$ concentrations of the extract. The graph (G) represents the effect of Melissa officinalis ethanolic extract on $\mathrm{NCl}-\mathrm{H} 460$ cellular viability following $48 \mathrm{~h}$ of treatment, determined with the trypan blue exclusion assay. The \% of viable cells was calculated in relation to blank. Conditions tested were: complete medium (blank); $\mathrm{Gl}_{50}$ and $\mathrm{Gl}_{75}$ concentrations of the ethanolic extract $(\mathrm{EtOH})$ and the solvent (DMSO) concentration corresponding to the one used in each extract concentration (CTR 50 and CTR 75). Doxorubicin (DOXO) $17 \mathrm{nM}$ was used as a positive control. Results are the mean \pm S.E. of three independent experiments. * indicates $p \leq 0.05$ between the extract treatment and blank.

tage of cells in the different phases of the cell cycle. However, in cells treated with the $\mathrm{GI}_{75}$ concentration of the ethanolic extract of Melissa officinalis there was a statistically significant decrease in the $\%$ of cells in the G2/M phase of the cell cycle (Fig. 3).

In order to verify whether the extract has an effect on cellular apoptosis, the Annexin V-FITC/PI assay was performed by flow cytometry. The ethanolic extract of Melissa officinalis induced apoptosis on NCI-H460 cells in both tested concen-

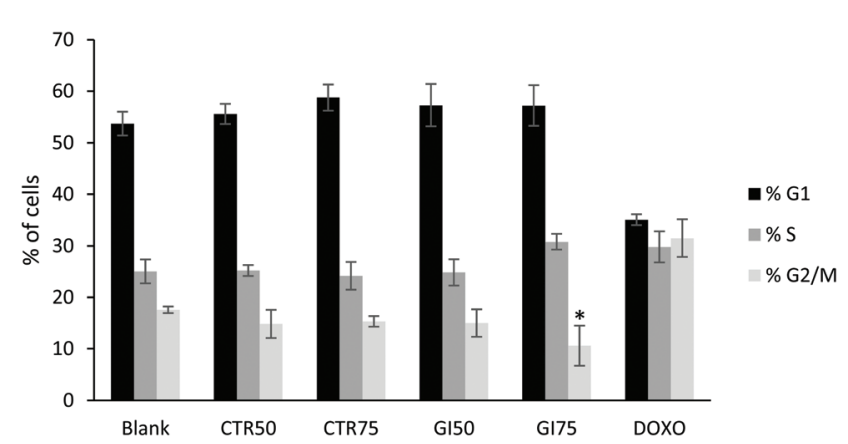

Fig. 3 Effect of Melissa officinalis ethanolic extract on the $\mathrm{NCl}-\mathrm{H} 460$ cell cycle profile. Cells were treated for $48 \mathrm{~h}$ with complete medium (blank); with the extract at a concentration that inhibited cell growth by $50 \%\left(\mathrm{Gl}_{50}, 100.9 \mu \mathrm{g} \mathrm{mL}^{-1}\right)$ or $75 \%\left(\mathrm{Gl}_{75}, 180.0 \mu \mathrm{g} \mathrm{mL}^{-1}\right)$ or with DMSO at concentrations corresponding to the extract $\mathrm{Gl}_{50}$ (CTR 50) or $\mathrm{Gl}_{75}$ (CTR 75). Cells were also treated with $17 \mathrm{nM}$ of doxorubicin (DOXO), used as a positive control. Results are the mean \pm S.E. of three independent experiments. ${ }^{*}$ indicates $p \leq 0.05$ between the extract treatment and blank. trations when compared with blank and the respective controls (CTR 50 and CTR 75). When the cells were treated with the $\mathrm{GI}_{50}$ concentration of this extract, the \% of cells undergoing apoptosis increases from $4.1 \%$ in blank cells to $19.1 \%$. When the cells were treated with the $\mathrm{GI}_{75}$ concentration of the extract they presented $28.3 \%$ of cells in apoptosis (Table 3 ). These results show that the ethanolic extract of Melissa officinalis has a potent and dose-dependent effect on cellular apoptosis in NCI-H460 cells.

Other studies have previously shown the apoptotic activity of other types of Melissa officinalis extracts in human breast cancer cells. ${ }^{12}$ Nevertheless, the effect of the ethanolic extract of this plant on the apoptosis of NCI-H460 cells has, to our knowledge, never been previously reported.

Table 3 Apoptosis levels of $\mathrm{NCl}-\mathrm{H} 460$ cells treated with Melissa officinalis ethanolic extract

\begin{tabular}{lc}
\hline Conditions $^{a}$ & $\%$ Apoptosis \\
\hline Blank & $4.1 \pm 1.1$ \\
CTR 50 & $4.1 \pm 1.5$ \\
CTR 75 & $6.7 \pm 3.8$ \\
GI $_{50}$ & $19.1 \pm 4.0$ \\
GI $_{75}$ & $28.3 \pm 6.5$ \\
DOXO & $44.7 \pm 6.4$
\end{tabular}

${ }^{a}$ Cells were treated for $48 \mathrm{~h}$ with complete medium (blank); with the $\mathrm{GI}_{50}$ and $\mathrm{GI}_{75}$ concentrations of the extract or with DMSO at concentrations corresponding to the extract $\mathrm{GI}_{50}$ (CTR 50) and $\mathrm{GI}_{75}$ (CTR 75). Doxorubicin (DOXO) at $17 \mathrm{nM}$ was used as a positive control. Results are represented as the mean \pm S.E. of three independent experiments. 
A

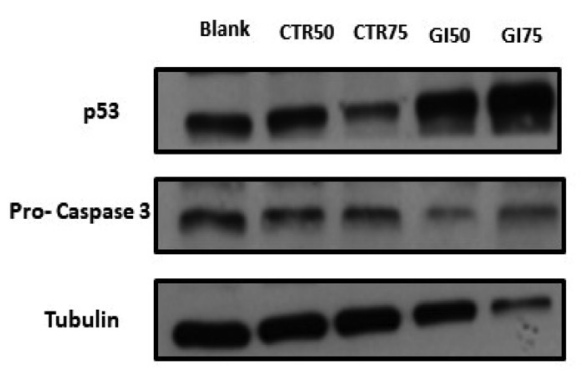

B

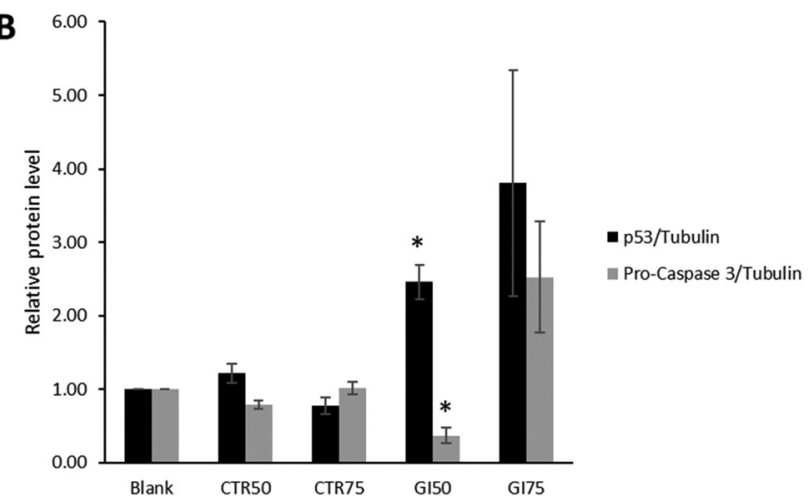

Fig. 4 Expression of apoptosis-related proteins in $\mathrm{NCl}-\mathrm{H} 460$ cells following $48 \mathrm{~h}$ treatment with the ethanolic extract of Melissa officinalis. Treatments were performed in complete medium (blank); vehicle of each condition (DMSO; CTR 50 and CTR 75) or with the Gl ${ }_{50}$ or $\mathrm{Gl}_{75} \mathrm{concen}$ trations of the ethanolic extract of Melissa officinalis. (A) Western Blot images are representative of three independent experiments. Tubulin was used as a loading control. (B) Densitometry analysis of the western Blot. Results are the mean \pm S.E. of three independent experiments and are expressed after normalization of the values obtained for each protein with the values obtained for tubulin. * indicates $p \leq 0.05$ between the extract treatment and blank.

The effect of the ethanolic extract on the expression levels of proteins involved in the cell cycle and apoptosis was also assessed. Results obtained from the western blot analysis showed a significant increase in the levels of p53 expression in treatments with the $\mathrm{GI}_{50}$ and $\mathrm{GI}_{75}$ concentrations of the extract, when compared with the blank and the controls (Fig. 4). This is in agreement with the results obtained in the cell cycle and apoptosis analysis, since it is known that an increase in the levels of p53 expression may be responsible for alterations in the cell cycle and an increase in apoptotic levels. ${ }^{28-31}$ In addition, the $\mathrm{GI}_{50}$ concentration of the ethanolic extract of Melissa officinalis decreased the expression levels of pro-caspase 3 when compared with the blank and the control cells. This is in agreement with the results obtained with the Annexin assay, since a reduction of pro-caspase 3 levels is indicative of the activation of caspase cleavage in the late stages of apoptosis. ${ }^{32-34}$ Unfortunately, when treating cells with the $\mathrm{GI}_{75}$ concentration of this extract, it was not possible to properly analyze the expression of these proteins since the obtained results varied substantially between experiments (high error bars of Fig. 4B), probably due to the high levels of apoptosis in the cells treated with the extract. Nevertheless, the results obtained with the $\mathrm{GI}_{50}$ treatment further confirmed that the ethanolic extract of Melissa officinalis induces apoptosis in NCI-H460 cells.

\section{Conclusions}

Previous studies have investigated the antitumor effects of the aqueous, ethanolic and hydroalcoholic extracts of Melissa officinalis. Nevertheless, the mechanism of action of such extracts was never previously investigated. The results here obtained revealed that the ethanolic extract presented the highest cell growth inhibitory potential in all the human tumor cell lines tested. The most sensitive cells to this extract treatment were the non-small cell lung cancer cells (NCI-H460). Furthermore, results showed that this extract affects the cell cycle profile of NCI-H460 cells and induces cell death by apoptosis. This study highlights the importance of studying the ethanolic extract of Melissa officinalis as a source of bioactive compounds with antitumor activity.

\section{Conflicts of interest}

The authors declare no conflict of interest.

\section{Acknowledgements}

This work was financed by the FEDER - Fundo Europeu de Desenvolvimento Regional through the COMPETE 2020 Operational Programme for Competitiveness and Internationalisation (POCI), Portugal 2020, and by Portuguese funds through FCT - Fundação para a Ciência e Tecnologia/ Ministério da Ciência, Tecnologia e Inovação in the framework of the project "Institute for Research and Innovation in Health Sciences" (POCI-01-0145-FEDER-007274). The authors are also grateful to FCT and FEDER under Programme PT2020 for financial support to CIMO (UID/AGR/00690/2013) and L. Barros contract; and to FEDER-Interreg España-Portugal programme for financial support through the project 0377_Iberphenol_6_E.

\section{(4) Interreg \\ España - Portugal}

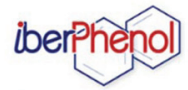

\section{Notes and references}

1 D. J. Newman and G. M. Cragg, Natural Products as Sources of New Drugs from 1981 to 2014, J. Nat. Prod., 
2016, 79(3), 629-661. PubMed PMID: 26852623. Epub 2016/ 02/09. eng.

2 G. M. Cragg and D. J. Newman, Natural products: a continuing source of novel drug leads, Biochim. Biophys. Acta, Gen. Subj., 2013, 1830(6), 3670-3695.

3 E. Rajesh, L. S. Sankari, L. Malathi and J. R. Krupaa, Naturally occurring products in cancer therapy, J. Pharm. BioAllied Sci., 2015, 7(Suppl 1), S181.

4 S. Aliya, Y. P. Devi and A. Uma, Plants as Potential Resources of Anticancer Drugs, Curr. Trends Biotechnol. Pharm., 2016, 10(1), 92-107.

5 A. J. Montero, B. Adams, C. M. Diaz-Montero and S. Gluck, Nab-paclitaxel in the treatment of metastatic breast cancer: a comprehensive review, Expert Rev. Clin. Pharmacol., 2011, 4(3), 329-334. PubMed PMID: 22114779. Epub 2011/11/26. eng.

6 M. C. Wani and S. B. Horwitz, Nature as a remarkable chemist: a personal story of the discovery and development of Taxol, Anti-Cancer Drugs, 2014, 25(5), 482-487. PubMed PMID: 24413390. Pubmed Central PMCID: PMC3980006. Epub 2014/01/15. eng.

7 A. C. Sousa, C. R. Gattass, D. S. Alviano, C. S. Alviano, A. F. Blank and P. B. Alves, Melissa officinalis L. essential oil: antitumoral and antioxidant activities, J. Pharm. Pharmacol., 2004, 56(5), 677-681.

8 H. Moradkhani, E. Sargsyan, H. Bibak, B. Naseri, M. SadatHosseini, A. Fayazi-Barjin, et al., Melissa officinalis L., a valuable medicine plant: A review, J. Med. Plants Res., 2010, 4(25), 2753-2759.

9 N. Mimica-Dukic, B. Bozin, M. Sokovic and N. Simin, Antimicrobial and antioxidant activities of Melissa officinalis L.(Lamiaceae) essential oil, J. Agric. Food Chem., 2004, 52(9), 2485-2489.

10 A. Jahanban-Esfahlan, S. Modaeinama, M. Abasi, M. M. Abbasi and R. Jahanban-Esfahlan, Anti Proliferative Properties of Melissa officinalis in Different Human Cancer Cells, Asian Pac. J. Cancer Prev., 2015, 16(14), 57035707.

11 M. A. Encalada, K. M. Hoyos, S. Rehecho, I. Berasategi, M. G.-Í. de Ciriano, D. Ansorena, et al., Anti-proliferative effect of Melissa officinalis on human colon cancer cell line, Plant Foods Hum. Nutr., 2011, 66(4), 328-334.

12 S. U. Saraydin, E. Tuncer, B. Tepe, S. Karadayi, H. Ozer, M. Sen, et al., Antitumoral effects of Melissa officinalis on breast cancer in vitro and in vivo, Asian Pac. J. Cancer Prev., 2012, 13(6), 2765-2770.

13 M. I. Dias, L. Barros, M. J. Sousa and I. C. Ferreira, Systematic comparison of nutraceuticals and antioxidant potential of cultivated, in vitro cultured and commercial Melissa officinalis samples, Food Chem. Toxicol., 2012, 50(6), 1866-1873.

14 L. Barros, M. Dueñas, M. I. Dias, M. J. Sousa, C. Santos-Buelga and I. C. Ferreira, Phenolic profiles of cultivated, in vitro cultured and commercial samples of Melissa officinalis L. infusions, Food Chem., 2013, 136(1), 1-8.
15 S. M. F Bessada, J. C. M. Barreira, L. Barros, I. C. F. R. Ferreira and M. B. P. P. Oliveira, Phenolic profile and antioxidant activity of Coleostephus myconis (L.) Rchb.f.: An underexploited and highly disseminated species, Ind. Crops Prod., 2016, 89, 45-51.

16 P. Skehan, R. Storeng, D. Scudiero, A. Monks, J. McMahon, D. Vistica, et al., New colorimetric cytotoxicity assay for anticancer-drug screening, JNCI, J. Natl. Cancer Inst., 1990, 82(13), 1107-1112.

17 J. M. Pereira, V. Lopes-Rodrigues, C. P. Xavier, M. J. Lima, R. T. Lima, I. C. Ferreira, et al., An aqueous extract of tuberaria lignosa inhibits cell growth, alters the cell cycle profile, and induces apoptosis of NCI-H460 tumor cells, Molecules, 2016, 21(5), 595.

18 M. J. Lima, D. Sousa, R. T. Lima, A. M. Carvalho, I. C. Ferreira and M. H. Vasconcelos, Flower extracts of Filipendula ulmaria (L.) Maxim inhibit the proliferation of the NCI-H460 tumour cell line, Ind. Crops Prod., 2014, 59, 149-153.

19 F. S. Reis, D. Sousa, L. Barros, A. Martins, P. Morales, I. C. Ferreira, et al., Leccinum vulpinum Watling induces DNA damage, decreases cell proliferation and induces apoptosis on the human MCF-7 breast cancer cell line, Food Chem. Toxicol., 2016, 90, 45-54.

20 M. H. Vasconcelos, S. S. Beleza, C. Quirk, L. Maia, C. Sambade and J. E. Guimarães, Limited synergistic effect of antisense oligonucleotides against bcr-abl and transferrin receptor mRNA in leukemic cells in culture, Cancer Lett., 2000, 152(2), 135-143.

21 O. H. Lowry, N. J. Rosebrough, A. L. Farr and R. J. Randall, Protein measurement with the Folin phenol reagent, J. Biol. Chem., 1951, 193(1), 265-275.

22 G. L. Peterson, Review of the Folin phenol protein quantitation method of Lowry, Rosebrough, Farr and Randall, Anal. Biochem., 1979, 100(2), 201-220.

23 A. Preto, J. Goncalves, A. P. Rebocho, J. Figueiredo, A. M. Meireles, A. S. Rocha, et al., Proliferation and survival molecules implicated in the inhibition of BRAF pathway in thyroid cancer cells harbouring different genetic mutations, BMC Cancer, 2009, 9, 387. PubMed PMID: 19878585. Pubmed Central PMCID: PMC2776025. Epub 2009/11/03. eng.

24 L. Gobbo-Neto and N. P. Lopes, Plantas medicinais: fatores de influência no conteúdo de metabólitos secundários, Quim. Nova, 2007, 30(2), 374.

25 E. Pereira, A. Antonio, J. C. M. Barreira, C. Santos-Buelga, L. Barros and I. Ferreira, How gamma and electron-beam irradiations modulate phenolic profile expression in Melissa officinalis L. and Melittis melissophyllum L, Food Chem., 2018, 240, 253-258. PubMed PMID: 28946270. Epub 2017/09/28. eng.

26 M. Carocho, L. Barros, R. C. Calhelha, A. Ćirić, M. Soković, C. Santos-Buelga, et al. Melissa officinalis L. decoctions as functional beverages: a bioactive approach and chemical characterization, Food Funct., 2015, 6(7), 2240-2248. 
27 T. Miron, M. Herrero and E. Ibáñez, Enrichment of antioxidant compounds from lemon balm (Melissa officinalis) by pressurized liquid extraction and enzyme-assisted extraction, J. Chromatogr., A, 2013, 1288, 1-9.

28 K. H. Vousden and C. Prives, Blinded by the Light: The Growing Complexity of p53, Cell, 2009, 137(3), 413-431. PubMed PMID: 19410540. Epub 2009/05/05. eng.

29 K. H. Vousden, Outcomes of p53 activation-spoilt for choice, J. Cell Sci., 2006, 119(Pt 24), 5015-5020. PubMed PMID: 17158908. Epub 2006/12/13. eng.

30 E. Wawryk-Gawda, P. Chylinska-Wrzos, M. Lis-Sochocka, K. Chlapek, K. Bulak, M. Jedrych, et al., P53 protein in proliferation, repair and apoptosis of cells, Protoplasma, 2014, 251(3), 525-533. PubMed PMID: 24043441. Pubmed Central PMCID: PMC3997830. Epub 2013/09/18. eng.
31 D. Speidel, The role of DNA damage responses in p53 biology, Arch. Toxicol., 2015, 89(4), 501-517. PubMed PMID: 25618545. Epub 2015/01/27. eng.

32 I. Budihardjo, H. Oliver, M. Lutter, X. Luo and X. Wang, Biochemical pathways of caspase activation during apoptosis, Annu. Rev. Cell Dev. Biol., 1999, 15, 269-290. PubMed PMID: 10611963. Epub 1999/12/28. eng.

33 G. M. Cohen, Caspases: the executioners of apoptosis, Biochem. J., 1997, 326(Pt 1), 1-16. PubMed PMID: 9337844. Pubmed Central PMCID: PMC1218630. Epub 1997/08/15. eng.

34 A. G. Porter and R. U. Janicke, Emerging roles of caspase-3 in apoptosis, Cell Death Differ., 1999, 6(2), 99-104. PubMed PMID: 10200555. Epub 1999/04/14. eng. 